\title{
Физико-географические исследования
}

УДК 591.9:599.426

\author{
К.А. Берников, В.П. Стариков, Н.В. Наконечный
}

\section{ГЕОГРАФИЯ РУКОКРЫЛЫХ ХАНТЫ-МАНСИЙСКОГО АВТОНОМНОГО ОКРУГА - ЮГРЫ ${ }^{1}$}

Целенаправленные исследования рукокрылых Ханты-Мансийского автономного округа - Югры позволили выявить шесть видов летучих мышей. Животные этой группы распространены по территории округа неравномерно, популяции разрежены. Низкая репродуктивная способность и численность, связанная с обитанием на границах ареалов рукокрылых Югры, способствовали включению всех видов летучих мышей в региональную Красную книгу. В настоящей статье, наряду с известными данными, авторами представлены современные сведения о распространении рукокрылых на территории Ханты-Мансийского автономного округа. Обсуждаются возможные причины особенностей распространения видов. Наибольшее видовое разнообразие характерно для южной и юго-западной части округа, что объясняется близостью мест возможных зимовок в пещерах Северного Урала. В центральной и северной части Югры встречены только экологически пластичные виды - северный кожанок и двухцветный кожан.

Ключевые слова: рукокрылые, Ханты-Мансийский автономный округ - Югра, география, особо охраняемые территории, экология.

DOI: $10.35634 / 2412-9518-2019-29-4-488-496$

В настоящее время на территории Ханты-Мансийского автономного округа - Югры (ХМАО Югры) известно обитание шести видов рукокрылых. Разреженность и редкость популяций этих животных в округе послужили основанием включения их в Красную книгу ХМАО - Югры [1]. Благодаря целенаправленным исследованиям рукокрылых с применением специальных технических средств были получены сведения о географии, некоторых аспектах экологии и биологии рукокрылых округа. В последние годы активно проводятся эколого-зоологические изыскания на особо охраняемых природных территориях (ООПТ) округа, в том числе труднодоступных и практически не изученных. Степень изученности рукокрылых ООПТ Югры неодинакова. Сравнительно полная и современная информация о видовом составе летучих мышей имеется для относительно высоких по рангу ООПТ - заповедников «Юганский» и «Малая Сосьва», где мониторинговые исследования позвоночных животных являются обязательными и проводятся регулярно [2].

В настоящей работе представлена современная информация о географии рукокрылых, полученная за семнадцатилетний период в ходе экспедиционных работ, выполненных авторами на ООПТ и других территориях Югры с привлечением результатов других исследователей.

\section{Материалы и методы исследований}

Сбор материала проводился авторами с мая по сентябрь в 2003-2019 гг.

При прокладке маршрутов предусматривалась максимальная вероятность встречи рукокрылых. Обследовались просеки, лесные дороги, участки вблизи строений. При поиске представителей рода Myotis особое внимание уделялось берегам водоемов (озер, карьеров, прудов) и водотоков (рек, ручьев). Для обнаружения рукокрылых использовался гетеродинный ультразвуковой детектор D-100 Pettersson Electronic AB. Учет рукокрылых проводили в сумеречное и ночное время. Поимку летучих мышей осуществляли посредством стационарных паутинных сетей. В качестве орудия активного лова использовали мобильную ловушку [3]. Всего было отловлено 397 особей летучих мышей.

Днем осматривались дуплистые деревья, щели и ниши в стенах построек, расположенные вблизи мест охоты и пролета животных, с целью обнаружения убежищ.

\footnotetext{
${ }^{1}$ Работа выполнена при частичной поддержке РФФИ № 18-44-860001/18 и Правительства Ханты-Мансийского автономного округа - Югры № 07/18/0360.
} 
Добытых зверьков обрабатывали по общепринятой методике [4]. После определения видовой принадлежности, пола, возраста, проведения измерений, животных метили. Мечение рукокрылых проводилось по методике К.К. Панютина [5] стандартными орнитологическими кольцами с обточенными углами и краями серии ХК. Помечено 209 особей.

\section{Результаты и их обсуждение}

Анализ литературных источников и результаты собственных исследований позволили дополнить опубликованную ранее информацию [6; 7] о современном составе рукокрылых, обитающих на ООПТ Югры. В настоящее время на этой территории отмечено пять видов рукокрылых: прудовая ночница (Myotis dasycneme), водяная ночница (M. daubentonii), ночница Брандта (M. brandtii), северный кожанок (Eptesicus nilssonii) и двухцветный кожан (Vespertilio murinus).

Заповедники. «Малая Сосьва». Находки Myotis brandtii и Eptesicus nilssonii - двух одинаково редких видов - сделаны на территории бывшего Кондо-Сосьвинского заповедника [8-10]. Эти виды отмечены и на современной территории заповедника «Малая Сосьва». Единственный экземпляр Myotis dasycneme (самец) был найден 2 сентября 1939 г. на воде одной из речных стариц у Шухтункурта [10].

«Юганский». Eptesicus nilssonii до недавнего времени считался единственным видом рукокрылых заповедника [11]. Позднее особи северного кожанка $(\mathrm{n}=12)$ отмечены в 2007 г. на р. Вуяяны [12], на стационаре «Каменный», в районе центральной усадьбы заповедника в с. Угут [2]. Vespertilio murinus для территории заповедника впервые приводят В.М. Переясловец и Т.С. Переясловец [12]: особи двухцветного кожана $(\mathrm{n}=7)$ отловлены на $\mathrm{pp}$. Вуяяны и Большой Юган. В последних работах $[2 ; 13]$ вид отмечен авторами в районе стационара «Каменный», где в настоящее время численно преобладает над северным кожанком.

Заказники. «Вогулка». Eptesicus nilssonii - 9 августа 2007 г. на территории базы заказника отловлена одна молодая самка.

«Кулуманский». Отмечен лет рукокрылых, видовая принадлежность которых не установлена (необходимы специальные исследования).

«Верхне-Кондинский». Myotis dasycneme - 2008 г., добыт на р. Конда в окрестностях кордона «Устье Лемьи». M. daubentonii - 2007, 2008 гг. в окрестностях кордонов «Нюрих» и «Устье Лемьи». M. brandtii - 2008 г. территория кордона «Устье Лемьи». Eptesicus nilssonii - добывался на территориях кордонов «Нюрих», «Устье Лемьи». Лёт рукокрылых отмечен в 2009-2010 г. на кордонах «Печерах» и «р. Эсс». В 2011 г. четыре особи учтены над берегом р. Эсс.

«Сургутский». В 2019 г. зарегистрирован лёт двухцветного кожана.

«Васпухольский». В сентябре 2019 г. по ультразвуковым сигналам отмечен лёт летучей мыши, однако диагностировать животное до вида не удалось. Предположительно особь принадлежала к роду Myotis.

Природные парки. «Сибирские Увалы». Eptesicus nilssonii - в 2003 г. 3 особи северного кожанка отловлены вблизи р. Глубокий Сабун, база «Брусовая» [14]. В 2007 г. добыты 4 особи на территории базы «Глубокий Сабун».

«Самаровский чугас». Vespertilio murinus - в августе 2005 г. одна особь добыта на территории Биатлонного центра г. Ханты-Мансийска [15]. В 2013 г. вид отмечен в окрестностях научного стационара урочища «Острова» - остов Большой Чухтинский [13], в 2015 г. и 2019 г. - в окр. д. Шапша. Eptesicus nilssonii зарегистрирован в окрестностях д. Шапша в 2015 г. и в 2019 г.

«Кондинские озера». M. brandtii - один экземпляр отмечен среди построек поселка лесников на юго-западном берегу озера Арантур. Eptesicus nilssonii отмечен в 2005 г. над огородами поселка лесников на юго-западном берегу озера Арантур, две особи вида - в сосняке лишайниковом на мореновых буграх в районе стационара [17]. Отмечая недостаточную изученность рукокрылых парка, авторы монографии [17] считают возможным обитание на рассматриваемой территории Myotis dasycneme, Vespertilio murinus и Myotis mystacinus (усатая ночница). Однако, на наш взгляд, встреча ее в природном парке мало вероятна, так как обитание усатой ночницы в Западной Сибири известно лишь для Южного Зауралья (Курганская область) [18]. Проведенные нами исследования в июле 2017 г. подтвердили обитание на территории парка Myotis brandtii, Eptesicus nilssonii и выявили новые виды Myotis dasycneme и Vespertilio murinus. Прогнозируем, что список можно дополнить - M. daubentonii. 
Памятники природы. «Луговские мамонты». В 2019 г. добыта одна самка Vespertilio murinus. Здесь же впервые на территории ХМАО зарегистрировано дневное убежище летучих мышей. Выводковая колония двухцветного кожана обнаружена в дупле осины на высоте около 5-6 м.

Видовой состав и обилие рукокрылых ООПТ ХМАО (табл.) зависит от географического положения, полнота сведений о них зависит от степени изученности конкретной территории. Например, относительно большое число видов летучих мышей, отмеченное в заказнике «Верхне-Кондинский», можно объяснить близостью Уральских гор, где рукокрылые находят благоприятные условия для зимовки, и ежегодными, целенаправленными исследованиями этой группы животных. Несмотря на непродолжительность экспедиционных выездов, ежегодная работа на территории заказника позволила получить оригинальные сведения об экологии, размножении, местах и времени охоты четырех видов рукокрылых, выявить новый вид - Myotis daubentonii. Для территории заказника можно прогнозировать нахождение двухцветного кожана.

Рукокрылые особо охраняемых природных территорий Югры, с указанием соотношения видов (число особей $(\%)$ )

\begin{tabular}{|c|c|c|c|c|c|c|}
\hline $\begin{array}{c}\text { № } \\
\Pi / \Pi\end{array}$ & ООПТ & 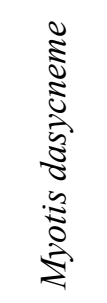 & 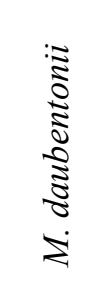 & 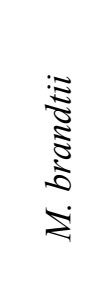 & 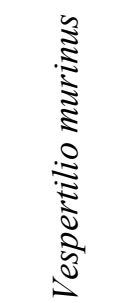 & 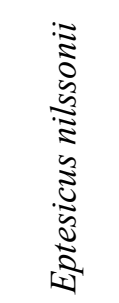 \\
\hline 1 & Заповедник «Малая Сосьва» & + & - & + & - & + \\
\hline 2 & \multicolumn{6}{|l|}{ Заповедник «Юганский» } \\
\hline & стационар «Вуяяны» & - & - & - & $2(8)$ & $13(92)$ \\
\hline & стационар «Каменный» & - & - & - & $41(95)$ & $3(5)$ \\
\hline 3 & \multicolumn{6}{|l|}{ Заказник «Верхне-Кондинский» } \\
\hline & кордон «Нюрих» & $1(14)$ & $1(14)$ & - & - & $5(72)$ \\
\hline & кордон «Устье Лемьи» & $1(13)$ & $2(25)$ & $2(25)$ & - & $3(37)$ \\
\hline & кордон «р.Эсс» & - & - & - & - & $4(100)$ \\
\hline \multirow[t]{2}{*}{4} & Заказник «Вогулка» & - & - & - & - & $1(100)$ \\
\hline & Заказник «Сургутский» & - & - & - & $1(100)$ & - \\
\hline 5 & \multicolumn{6}{|l|}{ Природный парк «Сибирские Увалы» } \\
\hline & база Брусовая & - & - & - & - & $3(100)$ \\
\hline & база «Глубокий Сабун» & - & - & - & - & $4(100)$ \\
\hline 6 & \multicolumn{6}{|l|}{ Природный парк «Самаровский чугас» } \\
\hline & урочище «Городские леса» & - & - & - & $1(100)$ & - \\
\hline & урочище «Острова» & - & - & - & $4(100)$ & - \\
\hline & урочище «Шапшинское» & - & - & - & $12(71)$ & $5(29)$ \\
\hline 7 & Природный парк «Кондинские озера» & $3(19)$ & - & $5(31)$ & $3(19)$ & $5(31)$ \\
\hline 8 & Памятник природы «Луговские мамонты» & - & - & - & $1(100)$ & - \\
\hline
\end{tabular}

Примечание: «+» вид отмечен, но современные данные по обилию вида отсутствуют; «-» вид не отмечен.

ООПТ, расположенные в северной и центральной частях округа, бедны видами летучих мышей. Северный кожанок, отмеченный в заказнике «Вогулка», вероятно, является единственным видом, способным обитать на его территории. Мы не исключаем обнаружение этого вида в природном парке «Нумто», заказниках «Сорумский», «Березовский» и др., при расширении районов исследований. Наши исследования рукокрылых округа показали, что в центральной части ХМАО встречаются два вида - двухцветный кожан и северный кожанок. Отсутствие представителей рода ночниц на этой территории подтверждают исследования В.М. Переясловец и Т.С. Переясловец [2; 12; 13]. В сборах авторов за десятилетний период ночницы в южной части ХМАО не регистрировались. 
Учитывая результаты исследований рукокрылых на ООПТ и других территориях округа, ниже приведены современные сведения о распространении летучих мышей Югры (2003-2019 г.).
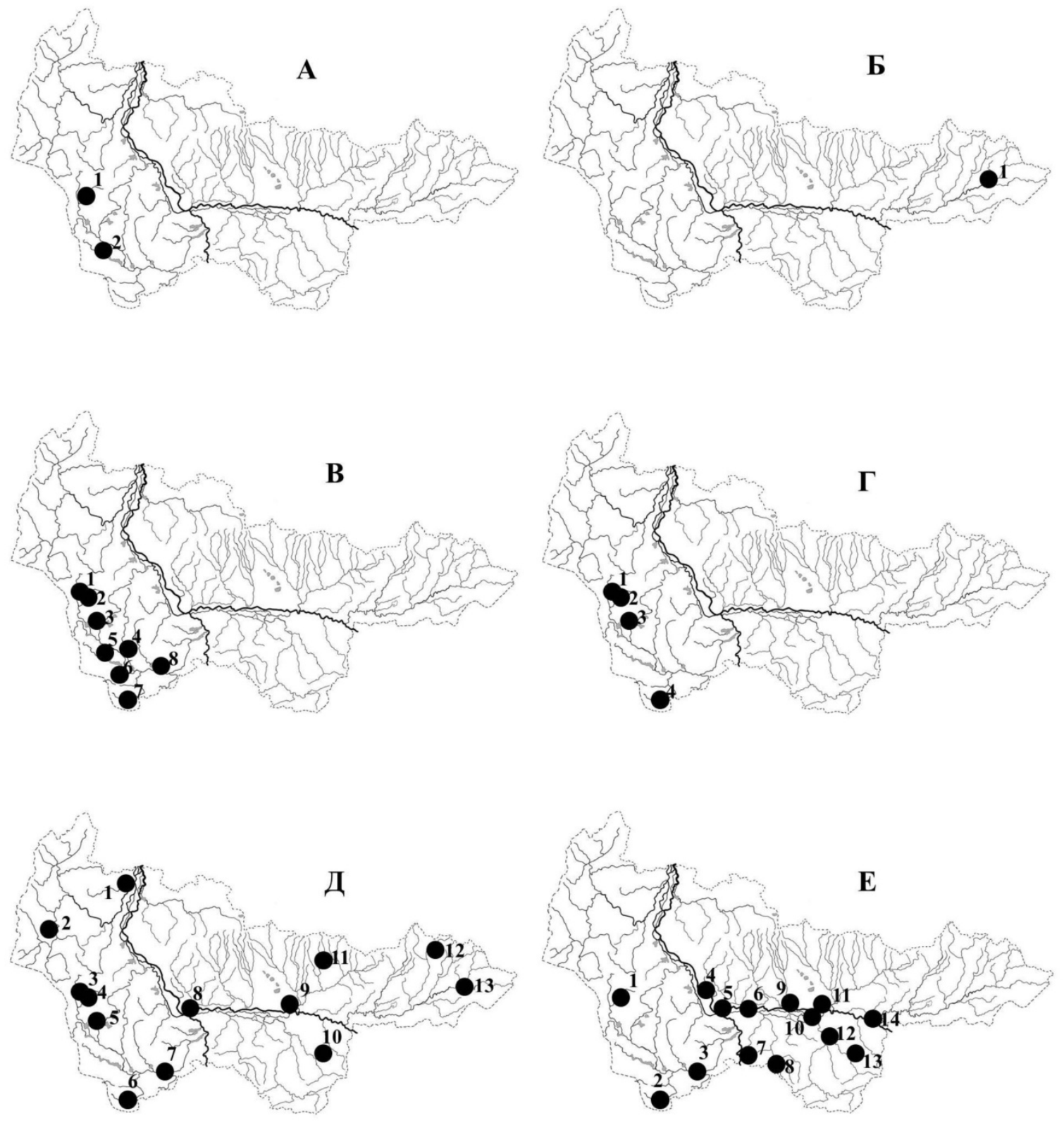

Рис. Современное распространение рукокрылых на территории Югры

Находки Myotis daubentonii на территории Ханты-Мансийского автономного округа (рис. А): 1 - заказник «Верхне-Кондинский» (р. Конда), 2 - окр. п. Ягодный (р. Канда).

Находки Myotis petax на территории Ханты-Мансийского автономного округа (рис. Б): 1 - окр. п. Корлики (р. Малый Корлик).

Находки Myotis dasycneme на территории Ханты-Мансийского автономного округа (рис. В): 1 заказник «Верхне-Кондинский» (р. Конда), 2 - природный парк «Кондинские озера», 3 - окр. г. Урай (р. Оурья), 4 - окр. бывшей д. Три Конды, 5 - окр. п. Ягодный (р. Канда), 6 - окр. п. Мортка (р. Леушинка), 7 - окр. п. Куминский, 8 - окр. п. Кондинское (р. Юконда).

Находки Myotis brandtii на территории Ханты-Мансийского автономного округа (рис. Г): 1 - заказник «Верхне-Кондинский» (р. Лемья), 2 - природный парк «Кондинские озера». 3 - окр. г. Урай (р. Оурья), 4 - окр. п. Куминский (р. Кума). 
Находки Eptesicus nilssonii на территории Ханты-Мансийского автономного округа (рис. Д): 1 - заказник «Вогулка», 2 - п. Хулимсунт, 3 - заказник «Верхне-Кондинский», 4 - природный парк «Кондинские озера», 5 - окр. г. Урай (р. Оурья), 6 - окр. п. Куминский, 7 - окр. п. Кондинское, 8 - природный парк «Самаровский чугас», 9 - г. Сургут, 10 - заповедник «Юганский», 11 - окр. г. Покачи, 12 - территория природного парка «Сибирские увалы», 13 - окр. п. Корлики.

Находки Vespertilio murinus на территории Ханты-Мансийского автономного округа (рис. Е): 1 - природный парк «Кондинские озера», 2 - окр. п. Куминский, 3 - окр. п. Кондинское (р. Юконда), 4 - памятник природы «Луговские мамонты», 5 - окр. г. Ханты-Мансийска, 6 - природный парк «Самаровский чугас», 7 - окр. п. Цынгалы, 8 - окр. п. Салым (р. Вандрас), 9 - окр. п. Сайгатино, 10 - окр. п.г.т. Барсово, 11 - г. Сургут, 12 - окр. д. Юган. 13 - заповедник «Юганский», 14 - окр. г. Нижневартовска.

По литературным данным северную границу ареала двухцветного кожана в Западной Сибири проводят до $60^{\circ}$ с.ш. [19]. Результаты наших учетов показали, что граница распространения этого вида на территории Югры проходит значительно севернее.

Ряд авторов связывает факт смещения северных границ ареалов некоторых млекопитающих с глобальным потеплением [20]. Комплекс новых благоприятных климатических факторов дает возможность рукокрылым постепенно расселяться. Этим отчасти объясняется их появление в местах, где ранее они отсутствовали. Например, В.Ю. Ильин [21] предполагает, что в зимнее время смягчение температуры воздуха в сочетании с увеличением толщины снежного покрова определяет лучшие условия для прохождения зимней спячки в щелях скальных пород относительно теплолюбивого Eptesicus serotinus serotinus на Самарской Луке. А.Н. Ляпунов [22] в северном направлении связывает расширение ареалов перелетных видов в условиях Кировской области с более высокой температурой апреля, наблюдаемой в последнее время. В свою очередь, это приводит к смещению сроков наступления фенологических явлений на более ранний период, в данном случае - появление летающих насекомых, являющихся основной кормовой базой летучих мышей.

Несмотря на возможное расширение ареала двухцветного кожана в северном направлении, отмечаем, что обширные пространства северной тайги в пределах Югры практически лишены рукокрылых. Некоторые авторы $[23 ; 24]$ причину данного явления видят в огромном количестве обширных болот и сплошных лесных массивов.

Весьма сомнительными, на наш взгляд, являются высказывания о значительном препятствии на распространение рукокрылых в северных широтах отсутствия темной части суток в летнее время. Известно про обитание рукокрылых в районах, расположенных севернее, где темная часть суток в летний период еще короче. Например, Север Скандинавии (68-70 с.ш.) - находки северного кожанка, включая колонии размножающихся самок [25]; в Европейской России самая северная находка зарегистрирована близ $69^{\circ}$ с.ш. [26]. Ввиду этого сложно назвать сам по себе режим освещения в летнее время «значительным препятствием» для рукокрылых.

И.П. Лаптев [27], рассматривая расположение точек нахождения летучих мышей по территории таежной зоны и вообще всей Западной Сибири, заметил, что рукокрылые в основном группируются около горных систем Урала и Алтая. Летучие мыши встречаются реже, чем далее от них располагаются указанные территории. Отсутствие подходящих пещер на большей части Западной Сибири объясняет и полное отсутствие здесь узкоспециализированных пещерников [23].

\section{Заключение}

Несмотря на то, что исследования рукокрылых в Югре значительно расширились, степень изученности летучих мышей столь обширного региона остается недостаточной. В Югре существуют ООПТ, где рукокрылые не затронуты исследованиями вообще. Например, нет сведений о летучих мышах заказника «Ландинский» (возможно обитание 4-5 видов). Проведенные нами в 2007 г. в окрестностях пос. Корлики (Нижневартовский район) исследования показали относительно высокую численность северного кожанка и восточной ночницы - Myotis petax (в настоящее время единственное местонахождение в округе) [28], что делает территорию восточной части округа (в частности заказник Верхне-Вахский) перспективной для многолетних мониторинговых исследований рукокрылых.

Хироптерофауну Ханты-Мансийского автономного округа - Югры отличает низкое видовое разнообразие. Наиболее широко по территории округа распространены такие виды, как двухцветный кожан и северный кожанок. Доля этих видов в уловах также наиболее высокая. Ночницы (за исключением 
Myotis petax) отмечались нами в юго-западной и южной части округа. Доля ночниц в уловах низкая. Причина невысоких показателей встречаемости и обилия ночницы Брандта, возможно, связана с недостаточными исследованиями. По литературным данным прошлых лет [29] этот вид рукокрылых указывается, как наиболее обычный и относительно равномерно расселенный в равнинных районах Западной Сибири. Экологическая пластичность в выборе биотопов двухцветного кожана, северного кожанка и ночницы Брандта позволяет им широко распространяться в северной Палеарктике [30-32].

\section{Благодарности}

Работа выполнена при частичной поддержке РФФИ № 18-44-860001/18 и Правительства Ханты-Мансийского автономного округа - Югры № 07/18/0360.

\section{СПИСОК ЛИТЕРАТУРЫ}

1. Красная книга Ханты-Мансийского автономного округа - Югры: животные, растения, грибы. 2-е изд. / отв. ред. А.М. Васин, А.Л. Васина. Екатеринбург: Изд-во «Баско», 2013. 460 с.

2. Переясловец В.М., Переясловец Т.С. Современное состояние фауны рукокрылых заповедника «Юганский» // История и перспективы заповедного дела России: проблемы охраны, научных исследований и экологического просвещения: Материалы науч.-практ. конф. Улан-Удэ: Изд-во Бурятского научного центра СО РАН, 2012. C. 123-124.

3. Борисенко А.В. Мобильная ловушка для отлова рукокрылых // Plecotus et al. 1999. № 2. С. 10-19.

4. Кузякин А.П. Обработка рукокрылых для научных коллекций // Рукокрылые. М.: Наука, 1980. С. 289-298.

5. Панютин К.К. Рукокрылые // Итоги мечения млекопитающих. М.: Наука, 1980. С. 23-46.

6. Берников К.А., Стариков В.П. Результаты и перспективы исследований рукокрылых ООПТ Югры // Особенности рекреационного использования особо охраняемых природных территорий: материалы науч.-практ. конф. Ханты-Мансийск: ООО «Доминус», 2011. С. 150-157.

7. Берников К.А., Стариков В.П. Рукокрылые особо охраняемых природных территорий Ханты-Мансийского автономного округа - Югры // Современное состояние и перспектива развития сети особо охраняемых природных территорий в промышленно развитых регионах: материалы межрегион. конф., посвящ. 20-летию природного парка «Нумто»: сб. науч. статей. Екатеринбург: «Ассорти»; Нижневартовск: Изд-во Нижневарт. гос. ун-та, 2017. С. 15-20.

8. Скалон В.Н. Новые данные о фауне млекопитающих и птиц Сибири // Изв. государственного противочумного института. 1935. Т. 2. С. 137-149.

9. Раевский В.В. Образ жизни кондо-сосвинского соболя. М.: Изд-во Гл. управл. по заповедникам, 1947. 222 с.

10. Раевский В.В. Позвоночные животные Северного Зауралья. М.: Наука, 1982. 146 с.

11. Стрельников Е.Г., Стрельникова О.Г. Животный мир // Юганский заповедник. Тюмень: СофтДизайн, 1998. C. $40-62$.

12. Переясловец В.М., Переясловец Т.С. К фауне рукокрылых заповедника «Юганский» // Биологические ресурсы и природопользование: сб. науч. трудов. Сургут: Дефис, 2007. Вып. 10. С. 229-234.

13. Переясловец В.М., Переясловец Т.С. Эколого-морфологическая характеристика популяции двухцветного кожана в Юганском заповеднике // Динамика окружающей среды и глобальные изменения климата. 2015. T. 6, № 2. C. 15-18.

14. Стариков В.П. Мелкие млекопитающие заповедно-природного парка «Сибирские Увалы» // Экологические исследования восточной части Сибирских Увалов: сб. науч. тр. заповедно-природного парка «Сибирские Увалы». Нижневартовск: Приобье, 2003. Вып. 2. С. 125-132.

15. Стариков В.П., Берников К.А., Минигалин А.Д. Состояние и перспективы исследований рукокрылых (Chiroptera) в Ханты-Мансийском автономном округе (XМАO) // Биоресурсы и природопользование в Ханты-Мансийском автономном округе: проблемы и решения: сб. материалов Открытой окр. конф. в рамках акции «Спасти и сохранить». Сургут, 2006. С. 28-30.

16. Стариков В.П., Берников К.А., Старикова Т.М. и др. Мелкие млекопитающие природного парка «Самаровский чугас» // Мир науки, культуры, образования. 2014. № 4. С. 413-417.

17. Природный парк «Кондинские озера» / под ред. В.М. Калинина. Екатеринбург: ООО «УИПЦ», 2012. 398 с.

18. Снитько В.П., Снитько Л.В. Рукокрылые (Chiroptera, Vespertilionidae) Южного Зауралья (Курганская область) // Зоологический журнал. 2015. Т. 94. № 2. С.233-240.

19. Кузякин А.П. Отряд Рукокрылые // Определитель млекопитающих СССР. М.: Просвещение, 1965. С. 79-116.

20. Данилов А.Н., Малафеев Ю.М., Данилова М.Н. Изменения южных границ ареалов мелких млекопитающих в бассейне р. Хадыта-Яха на Южном Ямале // Современные проблемы зоо- и филогеографии млекопитающих: материалы конф. (Пенза, 15-20 мая 2009 г.). М.: Изд-во КМК, 2009. С. 29. 
21. Ильин В.Ю. Динамика ареалов трех видов рукокрылых на крайнем юго-востоке Европы // Plecotus et al. 2000. № 3. С. 43-49.

22. Ляпунов А.Н. Ареал и климат. Их взаимосвязь применительно к рукокрылым в условиях Кировской области // Актуальные проблемы биологии и экологии: сб. материалов XIII молодежной науч. конф. Сыктывкар, 2007. C. $157-159$.

23. Кузякин А.П. Летучие мыши. М.: Советская наука, 1950. 443 с.

24. Шубин Н.Г. Приспособление млекопитающих к условиям среды Западной Сибири (сравнительноэкологический аспект проблемы). Томск: Изд-во Томского ун-та, 1980. 194 с.

25. Rydell, J., Strann K.-B., Speakmann J.R. First record of breeding bats above the Arctic Circle: northern bats at $68-$ $70^{\circ} \mathrm{N}$ in Norway // J. Zool. 1994. Vol. 233, № 2. P. 335-339.

26. Богдарина С.В., Стрелков П.П. Распространение рукокрылых (Chiroptera) на севере европейской России // Plecotus et al. 2003. № 6. C. 7-28.

27. Лаптев И.П. Млекопитающие таежной зоны Западной Сибири. Томск: ТГУ, 1958. 285 с.

28. Берников К.А., Крускоп С.В., Стариков В.П. Восточная ночница (Myotis petax Hollister, 1912) - новый вид рукокрылых Ханты-Мансийского автономного округа // Современные проблемы биологических исследований в Западной Сибири и на сопредельных территориях: материалы Всерос. науч. конф. / отв. ред. В.П. Стариков. Сургут: Изд-во ООО «Таймер», 2011. С. 45-49.

29. Стуканова Т.Е. Видовой состав и относительная численность рукокрылых в Западной Сибири // Материалы Первого Всесоюз. совещ. по рукокрылым. Л., 1974. С. 82-84.

30. Jong J. Habitat use, home-range and activity pattern of the northern bat, Eptesicus nilssoni, in a hemiboreal coniferous forest // Mammalia. 1994. Vol. 58, № 4. P. 535-548.

31. Крускоп С.В. Эколого-морфологическое исследование сообщества рукокрылых (Chiroptera) Подмосковья // Состояние териофауны в России и ближнем зарубежье: труды Междунар. совещ. (1-3 фев. 1995 г., Москва). M., 1996. C. 169-173.

32. Крускоп С.В. Эколого-морфологическое разнообразие гладконосых рукокрылых (Vespertilionidae, Chiroptera): автореф. дис. ... канд. биол. наук. М., 1998. 24 с.

Поступила в редакцию 14.11.2019

Берников Кирилл Александрович, кандидат биологических наук, доцент, зав. кафедрой биологии и биотехнологии

E-mail: bernikov kirill@mail.ru

Стариков Владимир Павлович, доктор биологических наук, профессор

кафедры биологии и биотехнологии

E-mail: vp_starikov@mail.ru

Наконечный Николай Владимирович, кандидат биологических наук,

ведущий научный сотрудник научно образовательного центра

E-mail: yyd@list.ru

БУ ВО «Сургутский государственный университет»

628412, Россия, г. Сургут, просп. Ленина, 1

\section{K.A. Bernikov, V.P. Starikov, N.V. Nakonechnyi GEOGRAPHY OF BATS IN KHANTY-MANSIYSK AUTONOMOUS OKRUG - YUGRA}

DOI: $10.35634 / 2412-9518-2019-29-4-488-496$

Targeted studies of bats in Khanty-Mansiysk Autonomous Okrug-Yugra revealed six species of bats. Animals of this group are spread throughout the region not-evenly, the populations are rarer. Low reproductive capacity and the number associated with living on the border of habitats in Yugra contributed to the inclusion of all species of bats in the regional Red Book. In this article, along with known data, the authors present modern information on the distribution of bats in the territory of the Khanty-Mansiysk Autonomous Okrug. Possible causes of local distribution of species are discussed. The largest species diversity is characteristic of the southern and southwestern part of the region, which is due to the proximity of possible winter sites in the caves of the Northern Ural. In the central and northern part of Yugra there are only ecologically flexible species - the Northern bat and Parti-colored bat.

Keywords: bats, Khanty-Mansiysk Autonomous Okrug-Yugra, geography, specially protected areas, ecology. 


\section{REFERENCES}

1. Krasnaya kniga Khanty-Mansiyskogo avtonomnogo okruga - Yugry: zhivotnye, rasteniya, griby [The Red Book of Khanty-Mansi Autonomous Okrug: animals, plants, fungi], 2nd ed., Vasin A.M. and Vasina A.L. (ed), Ekaterinburg: Basko Publ., 2013, 460 p. (in Russ.).

2. Pereyaslovets V.M., Pereyaslovets T.S. [Current status of the chiropteran's fauna "Yugansky" reserve], in Mater. nauch.-prakt. konf. "Istoriya i perspektivy zapovednogo dela Rossii: problemy okhrany, nauchnykh issledovaniy $i$ ekologicheskogo prosveshcheniya», Ulan-Ude: Izd-vo Buryatskogo nauchnogo tsentra SO RAN, 2012, pp. 123-124 (in Russ.).

3. Borisenko A.V. [Mobile trap for capture chiropterans], in Plecotus et al. 1999, no. 2, pp. 10-19 (in Russ.).

4. Kuzyakin A.P. [Bats processing for scientific collections], in Rukokrylye. Moscow: Nauka Publ., 1980, pp. 289-298 (in Russ.).

5. Panyutin K.K. Rukokrylye. [Chiropterans], in Itogi mecheniya mlekopitayushchikh, Moscow: Nauka, 1980, pp. 2346 (in Russ.).

6. Bernikov K.A., Starikov V.P. [Result and prospects for research of chiropterans of protected areas in Ugra], in $\mathrm{Ma}$ ter. nauch.-prakt. konf. "Osobennosti rekreatsionnogo ispol'zovaniya osobo okhranyaemykh prirodnykh territoriy", Khanty-Mansiysk: OOO Dominus Publ., 2011, pp. 150-157 (in Russ.).

7. Bernikov K.A., Starikov V.P. [Chiropterans of protected areas in Khanty-Mansi Autonomous Okrug - Ugra], in Mater. Mezhregion. konf. "Sovremennoe sostoyanie i perspektiva razvitiya seti osobo okhranyaemykh prirodnykh territoriy $v$ promyshlenno razvitykh regionakh", posvyashchennoy 20-letiyu prirodnogo parka "Numto", Ekaterinburg: Assorti Publ., Nizhnevartovsk: Nizhnevartovskiy. Gos. Univ., 2017, pp. 15-20 (in Russ.).

8. Skalon V.N. [New data on the fauna of mammals and birds of Siberia], in Izvestiya gosudarstvennogo protivochumnogo instituta, 1935, vol. 2, pp. 137-149 (in Russ.).

9. Raevskiy V.V. Obraz zhizni kondo-sosvinskogo sobolya [Life-style of Condo-Soswin sable], Moscow: Glavnoe upravl. po zapovednikam Publ., 1947, 222 p. (in Russ.).

10. Raevskiy V.V. Pozvonochnye zhivotnye Severnogo Zaural'ya [Vertebrate animals of Northern Trans-Urals], Moscow: Nauka, 1982, 146 p. (in Russ.).

11. Strel'nikov E.G., Strel'nikova O.G. [Animal world], in Yuganskiy zapovednik, Tyumen': SoftDizayn Publ., 1998, pp. 40-62 (in Russ.)

12. Pereyaslovets V.M., Pereyaslovets T.S. [To the fauna of chiropterans of the Yugansky reserve], in Biologicheskie resursy i prirodopol'zovanie, Surgut: Defis Publ., 2007, iss. 10, pp. 229-234 (in Russ.).

13. Pereyaslovets V.M., Pereyaslovets T.S. [Ecological and morphological characteristics of the Particoloured Bat population in the Yugansky reserve], in Dinamika okruzhayushchey sredy i global'nye izmeneniya klimata, 2015. vol. 6, no 2. pp. 15-18 (in Russ.).

14. Starikov V.P. [Small mammals of the "Siberian Uvaly" nature reserve], in Sborn. nauch. tr. zapovedno-prirodnogo parka "Sibirskie Uvaly" "Ekologicheskie issledovaniya vostochnoy chasti Sibirskikh Uvalov", Nizhnevartovsk: Priob'e Publ., 2003, iss. 2, pp. 125-132 (in Russ.).

15. Starikov V.P., Bernikov K.A., Minigalin A.D. [Conditions and perspectives of research on Chiroptera in KhantyMansiy autonomous okrug (KhMAO)], in Sborn. Mater. Otkrytoy okr. konf. "Bioresursy i prirodopol'zovanie v Khanty-Mansiyskom avtonomnom okruge: problemy $i$ resheniya" v ramkakh aktsii "Spasti i sokhranit'", Surgut, 2006, pp. 28-30 (in Russ.).

16. Starikov V.P., Bernikov K.A., Starikova T.M. (ed). [Small mammals in nature park "Samarovskiy Chugas"], in Mir nauki, kul'tury, obrazovaniya, 2014, no. 4, pp. 413-417 (in Russ.).

17. Prirodnyy park «Kondinskie ozera» [Nature park "Kondinskiye Ozera"], V.M. Kalinina (ed). Ekaterinburg: OOO UIPTs Publ., 2012, 398 p. (in Russ.).

18. Snit'ko V.P., Snit'ko L.V. [Bats (Chiroptera, Chiroptera) of Southern Ural (Kurgan region)], in Journal of Zoology, 2015, vol. 94, no. 2, pp. 233-240 (in Russ.).

19. Kuzyakin A.P. Otryad Rukokrylye [Order Chiroptera], in Opredelitel' mlekopitayushchikh SSSR, Moscow: Prosveshchenie, 1965, pp.79-116 (in Russ.).

20. Danilov A.N., Malafeev Yu.M., Danilova M.N. [Changes in the southern bounds of small mammals habitats in the Khadyta-Yakha river basin in South Yamal], in Mater. konf. "Sovremennye problemy zoo-i filogeografii mlekopitayushchikh”, Moscow: KMK Publ., 2009, pp. 29 (in Russ.).

21. Il'in V.Yu. [Dinamics of the areas of three species of bats in the far south-east of Europe], in Plecotus et al, 2000, no. 3, pp. 43-49 (in Russ.)

22. Lyapunov A.N. [Habitat and climate. Their interconnections in relation to bats in the conditions of Kirov region], in Sborn. Mater. XIII molodezhnoy nauch. konf. “Aktual'nye problemy biologii i ekologii”, Syktyvkar, 2007, pp. 157-159 (in Russ.).

23. Kuzyakin A.P. Letuchie myshi [Bats]. Moscow: Sovetskaya nauka, 1950, 443 p. (in Russ.) 
24. Shubin N.G. Prisposoblenie mlekopitayushchikh k usloviyam sredy Zapadnoy Sibiri (sravnitel'no-ekologicheskiy aspekt problemy) [Mammals adaptation to conditions of Western Siberia environment (comparatively ecological aspect of the problem], Tomsk: Tomskiyi Univ., 1980, 194 p. (in Russ.).

25. Rydell J., Strann K.B., Speakmann J.R. [First record of breeding bats above the Arctic Circle: northern bats at 68 $70^{\circ} \mathrm{N}$ in Norway], in Journal of Zoology, 1994, vol. 233, no. 2, pp. 335-339.

26. Bogdarina S.V., Strelkov P.P. [Spreading of bats (Chiroptera) on north European part of Russia], in Plecotus et al. 2003, no. 6, pp. 7-28 (in Russ.).

27. Laptev I.P. Mlekopitayushchie taezhnoy zony Zapadnoy Sibiri [Mammals of taiga area of Western Siberia]. Tomsk: Tomskiy Gos. Univ., 1958, 285 p. (in Russ.).

28. Bernikov K.A., Kruskop S.V., Starikov V.P. [Eastern water bat (Myotis petax Hollister, 1912) - new bat species of Khanty-Mansiy autonomous okrug], in Mater. Vseros. nauch. konf. "Sovremennye problemy biologicheskikh issledovaniy v Zapadnoy Sibiri i na sopredel'nykh territoriyakh", Surgut: Taymer Publ., 2011, pp. 45-49 (in Russ.).

29. Stukanova T.E. [Species composition and relative abundance of bats in Western Siberia], in Mater. Pervogo Vsesoyuz. soveshch. po rukokrylym, St. Petersburg, 1974, pp. 82-84 (in Russ.).

30. Jong J. Habitat use, home-range and activity pattern of the northern bat, Eptesicus nilssoni, in a hemiboreal coniferous forest, Journal of Mammalia. 1994, vol. 58, no. 4, pp. 535-548.

31. Kruskop S.V. [Ecological and morphological research of bats community (Chiroptera) in Moscow region], in $T r$. Mezhd. soveshch. "Sostoyanie teriofauny v Rossii i blizhnem zarubezh'e", Moscow, 1996, pp. 169-173 (in Russ.).

32. Kruskop S.V. [Ecological and morphological variety of family Vespertilionidae (Vespertilionidae, Chiroptera)], Abstract of dis. Cand. Biol. sci., Moscow, 1998, 24 p. (in Russ.).

Received 14.11.2019

Bernikov K.A., Candidate of Biology, Associate Professor, Head of Department of Biology \& Biotechnology E-mail: bernikov_kirill@mail.ru

Starikov V.P., Doctor of Biology, Professor

E-mail: vp_starikov@mail.ru

Nakonechnyi N.V., Candidate of Biology, leading researcher

E-mail: yyd@list.ru

Surgut State University

Prosp. Lenina, 1, Surgut, Russia, 628412 